\title{
Strategies of International Companies as a Research Problem of Geography of Enterprise
}

\begin{abstract}
The main goal of the article is to analyse strategies of international enterprises, undertaken in the processes of internationalisation and expansion into foreign markets. Due to the spatial dimension of these processes, the issues related to the strategies of large foreign investors also appear in the research of geography of enterprise. It is since the functioning of international enterprises can be understood as a result of processes arising from a combination of mutual relations between their management strategy and local conditions in their environment, which in turn affects the diverse range of spatial impacts. The presented study focuses on the analysis of strategies adopted at the highest organisational level, i.e. on comprehensive internationalisation strategies, which most synthetically reflect how enterprises operate on foreign markets. Subsequently, the paper presents the model concept of strategic orientations of C.A. Bartlett and S. Ghoshal, which due to the extended spectrum of identification criteria is more operational. Moreover, in the presented concept, the basic dimensions of internationalisation, i.e. the configuration of the organisational structure and the coordination of activities on international markets, indicate a significant geographical dimension of internationalisation processes. The presented conceptual model also points to new possibilities of interpreting the strategy of international enterprises using the I-R paradigm, which may be particularly useful for the research goals realised in the field of the geography of enterprise.
\end{abstract}

Keywords: geography of enterprise; international enterprises; internationalisation; strategies

Received: 21 May 2018

Accepted: 9 July 2018

Suggested citation:

Tobolska, A. (2018), Strategies of International Companies as a Research Problem of Geography of Enterprise. Prace Komisji Geografii Przemysłu Polskiego Towarzystwa Geograficznego [Studies of the Industrial Geography Commission of the Polish Geographical Society], 32(4), 48-68. https://doi.org/10.24917/20801653.324.3

\section{INTRODUCTION: JUSTIFICATION OF THE UNDERTAKEN RESEARCH AND THE PURPOSE OF THE STUDY}

For economic geography, modern times are marked by a particular paradox: the processes of decentralisation and flexibility of production increase the importance of small enterprises, and at the same time, in all industrialised countries, there is a wave 
of expansion and merger of large international enterprises. The number of the largest transnational corporations - the name used in the statistics on mega-enterprises in the annual UNCTAD reports - increased on a global scale from 37,000 in the early 1990s to over 103,000 in 2010, and the number of their branches, respectively, from 170,000 to 892,000 . These facts justify the increase of research interests of various academic disciplines in this group of global economy actors, including socio-economic geography, and in particular one of its trends, i.e. geography of enterprise (corporate geography). This research stream mainly includes analyses of the location, impact and spatial organisation of enterprises, including international ones (cf. e.g. McNee, 1960; Krumme, 1969; Dicken, 1990; Domański, 1997; Clark, Wrigley, 1997; Stryjakiewicz, 1999; Schamp, 2000; Taylor, Asheim, 2001; Maskell, 2001; Bathelt, Glückler, 2003; Tobolska, 2004a, 2013; Jones, 2005; Wieloński, 2005; Yeung, 2006; Śleszyński, 2007). In the research of geography of enterprise, of particular importance are specific spatial features that distinguish large international enterprises, which include the impact on changes in spatial economic structures, mainly through the transfer of their resources to subsidiary companies and in the form of direct foreign investments. Also through their strategies, e.g. in the field of marketing, product offer or contracts, they affect the international division of labour. Besides, foreign expansion is associated with decisions to choose new locations, especially for greenfield investments ("Windows of Locational Opportunity" according to Storper, Walker, 1989: 70, see also Domański, 2002: 198-199), which in turn is the standard issue of location theory. Since the 1990s in Polish literature on geography of enterprise there have been studies on various aspects of the location and operation of international corporations, including in the form of detailed monographic articles on selected corporations (e.g. Stryjakiewicz, Wajda, 2003; Wajda, Zalewska, 2003; Wajda, Zorićić-Wołek, 2003; Stryjakiewicz, 2004; Lizak, 2009; Tkocz, Żydzik, 2010; Bonar, 2011; Kilar, 2011; Boguś, 2012), or analyses regarding corporate expansion in quantitative terms, i.e. in the form of the inflow of foreign direct investments and their directions (incl. Sala, 2005; Tobolska, 2007, 2014; Wojciechowski, 2015), as well as the effects of this expansion, especially in relation to Polish economy (e.g. Stryjakiewicz, 1999; Domański, 2001, 2005, 2011; Hardy, 2002; Gierańczyk, Stańczyk, 2003; Sala, 2003; Brezdeń, 2004, 2006, 2016; Domański, Gwosdz, Huculak, Wiedermann, 2005; Wdowicka, 2005; Matykowski, Tobolska, 2006; 2009; Pavlínek, Domański, Guzik, 2009; Pakulska, 2010; Winter, 2010). A separate group of studies in this field includes the analyses of the location of corporate head offices (Zioło, Piróg, 2002; Rogacki, 2006; Zioło, 2006; Śleszyński, 2007, 2014, 2015; Kilar, 2014, 2015). General models of corporate behaviour were also formulated in the context of other companies and in the context of changes in the Polish industrial space (Zioło, 2003; Tobolska, 2004a, 2004b, 2006). The analysis of the impact of international corporations on local and regional development (e.g. Dziemianowicz, 1997; Stryjakiewicz, 1999, 2004; Domański, 2005; 2011; Sala, 2005, 2008; Kostrubiec, 2006; Wiedermann, 2007; Zioło, 2009; Tobolska, 2010a, 2010b, 2017) are an exciting trend of research. It should be added that many of the papers representing this research trend were published in the academic journals of the Industrial Geography Commission of the Polish Geographical Society, as a record of the research issues of the annual conferences of this Commission held at the Pedagogical University of Cracow.

However, it should be emphasised that contemporary research themes concerning the operation of international enterprises and related internationalisation processes 
and international production are mainly conducted on the basis of economic sciences, as well as organisational and management sciences. They focus on the new perspective of the issues related to organisation, strategy, intra-corporate specialisation, as well as learning processes of branches and their innovativeness (cf. e.g. Zorska, 1998, 2007, 2013, 2014; Rymarczyk, 2004, 2012a, 2012b; Yip, 2004; Cieślik, 2005, 2013; Kutschker, Schmid, 2005; Gorynia, 2007; Fonfara, 2009; Stępień, 2009; Rosińska-Bukowska, 2012; Oczkowska, 2013). A particularly interesting research trend concerns shaping of new roles of foreign branches, both for corporate strategy and links with entities operating in the branch's environment (cf. Zorska, 2007: 230-269, 2013, 2014; Stępień, 2009; Ząbkowicz, 2009; Cieślik, 2013; Gorynia, Samelak, 2013; and among foreign studies, e.g. Holm, Malmberg, Sölvell, 2003; Ivarsson, Johnsson, 2003; Phelps, MacKinnon, Stone, Braidford, 2003; Defever, 2006, 2012; Frigant, Layan, 2009; Winter, 2010). Hence the inspiration and concept of the presented study, whose primary goal is to analyse strategies of international enterprises, undertaken in the processes of internationalisation and expansion into foreign markets. Due to the spatial dimension of these processes, issues related to strategies undertaken by enterprises also appear in the research of geography of enterprise (Tobolska, 2017). It should be noted that the scope of influence of subsidiary production plants of large international enterprises in the local and regional space is primarily the result of investors' strategy and related strategic goals, i.e. strengthening of the competitive position. The strategic orientations adopted by the companies related to the internationalisation process of their activities, new ways of organising and functioning on international markets, as well as competitive strategies related to the use of different sources of competitive advantage on foreign markets, result in the shaping of different location orientations of their subsidiaries/branches. In turn, in new locations of the branches new connections and spatial arrangements are created, with a different scope of both economic and social dimensions. In this context, the functioning of multinational enterprises can be understood as the result of a process arising from a combination of mutual relations between their structure and management strategy, and local conditions in the enterprise environment, in a given place and time (see Schamp, 2000: 61). Therefore, it can be assumed that the starting point in the analysis of functioning of international enterprises is the identification of their strategy, which determines the ways and scope of impact of their branches in the local, regional and global space. This approach can, therefore, be considered as a suggestion for researching the problems of international business strategies characteristic of geography of enterprise.

\section{STRATEGIES OF INTERNATIONAL ENTERPRISES IN THE INTERNATIONALISATION PROCESS}

Decisions on how to function and achieve the set goals are made by enterprises in the form of a strategy, i.e. a specific long-term action plan; in the case of international enterprises, they additionally involve decisions on the ways and directions of their internationalisation. The presented study focuses on the analysis of strategies adopted at the topmost organisational level of these highly developed enterprises, i.e. on comprehensive internationalisation strategies, which in the most synthetic way reflect the ways in which enterprises operate on foreign markets, including the various relationships between organisational units and business partners (cf. Tobolska, 2017). Referring to 
the findings of J. Rymarczyk (2012a: 257), it should also be noted that the overall strategy of international enterprises stems mainly from the culturally diverse orientation of these companies, shaped under the influence of the entire complex of conditions under which business is conducted on foreign markets.

In the first stage of the analysis, apart from the review of various theoretical approaches on the issue of strategy in enterprises, the concept of a comprehensive corporate internationalisation strategy is also presented, followed by a model concept for the strategic orientation of C.A. Bartlett and S. Ghoshal (1987a, 1987b), which is more operational in nature. The choice of this model concept has been made mainly due to the relatively broadest spectrum of criteria for identifying the types of quality strategies distinguished by the authors. The most important criterion from the point of view of spatial analysis is the ability to recognise organisational structures that reflect the configuration and connections between branches of corporations, and at the same time characterise their strategy (according to A.D. Chandler, 1962: 13 "Structure follows strategy", cf. Kreikebaum, 1996: 136-138; Tobolska, 2004b: 121; Rymarczyk, 2012: 503).

The starting point in the analysis of comprehensive corporate internationalisation strategies is the assumption that when formulating the strategic orientation of the enterprise, general framework decisions regarding the internationalisation process are made, which reflect a comprehensive picture of the functioning of such an international organisation (Internationalisierungsgestalt/Internationalisierungsmuster, i.e. a character or pattern of internationalisation, according to Kutschker, Schmid, 2005: 278). They are further developed and refined as part of preparation of development strategies through expansion to particular foreign markets, or competition strategies of individual organisational units in specific markets (cf. Gorynia, 2007: 38; Romanowska, 2009: 22; Pierścionek, 2011: 10, 18-19; Oczkowska, 2013: 156). The decisions of the corporations about the way of entering foreign markets and the selection of competition strategies can be another step in deepening the analysis of international business strategies.

\section{Enterprise strategies - the multiplicity of approaches and definitions}

In the classical definition formulated by A.D. Chandler (1962: 10), the strategy is presented as "the process of defining the company's long-term goals and objectives and adopting directions of action, as well as allocating the resources necessary to achieve these goals" (cf. Kreikebaum, 1996: 26-27; Tobolska 2004b: 120; Gorynia, 2007: 30; Oczkowska, 2013: 152). However, the concept of a strategy has evolved significantly along with the changes in economy and management methods, as well as with the increase in the dependence of enterprises on an increasingly turbulent environment. In the new conditions of a strongly globalised economy, the strategy is perceived as a way to achieve a long-term competitive advantage in designated areas of activity (cf. e.g. Zorska, 1998: 146; Koźmiński, 1999: 97; Hatch, 2002: 113; Stabryła, 2006: 17; Fonfara, 2009: 18; Oczkowska, 2013: 153). In the literature on organisation and management theory, in particular in the field of strategic management, a lot of approaches and definitions of the term are presented, and their extensive review can be found in the papers by H. Mintzberg and J.B. Quinn (1991), M.E. Porter (1992), J. Jeżak (1993), K. Obłoja (1993, 2014), H. Kreikebaum (1996), A. Zorska (1998), K. Fonfara, M. Gorynia, E. Najlepszy, J. Schroeder (2000), M.J. Hatch (2002), P. Banaszyk (2002), Z. Pierścionek (2003, 
2011), R.W. Griffin (2004), E. Urbanowska-Sojkin, P. Banaszyk, H. Witczak (2004), G.S. Yip (2004), M. Kutschker and S. Schmid (2005), K. Sowa (2006), M. Gorynia (2007), E. Cyrson (2009), M. Romanowska (2009), J. Rymarczyk (2012a), M. Rosińska-Bukowska (2012), A. Tobolska (2017). In these quite diverse descriptions defining the concept of a strategy, however, there are several recurring common features, such as:

- a goal: a strategy is always associated with the formulation and implementation of the goal or "a bundle" of the company's long-term goals;

- a plan: a strategy is based on action planning in a given time horizon;

- resources, skills, competencies: these are the primary sources of a competitive advantage for enterprises; the strategy is mainly being based on them;

- the environment: the strategy reflects the reactions to changes in a turbulent and complex company environment.

Synthetic characteristics of the concept of the strategy are presented in Fig. 1.

There are many types of strategies undertaken in enterprises, which are distinguished depending on the adopted criteria, for instance, the following strategies can be identified due to the direction of the company's development: growth (investment), stabilisation and contraction (disinvestment, cf. e.g. Kreikebaum, 1996: 59 ). In turn, due to the development of products on the market H.I. Ansoff (1957: 114) distinguished strategies of market penetration, market development, product development, as well as vertical, horizontal and lateral diversification (cf. e.g. Gorynia, 2007: 38-40; Romanowska, 2009: 64-96, Oczkowska, 2013: 155). Its multi-level nature also influences the complexity of the strategy - usually in addition to the overall strategy of the company (corporate strategy), which characterises its mission and vision, as well as the primary goals, strategies are also formulated for individual organisational units or areas of activity (business strategies), and at the lowest hierarchical level of enterprises - partial strategies (functional/operational strategies), which constitute the implementation of a comprehensive strategy in the company's functional areas, e.g. supply, sales, marketing, production, financing, human resources, investments (cf. e.g. Griffin, 2004: 246247: Kutschker, Schmid, 2005: 797-811; Gorynia, 2007: 44-45; Romanowska, 2009: 22; Rymarczyk, 2004: 74-135, 2012a: 255-500; Oczkowska, 2013: 156). Moreover, Z. Pierścionek (2011: 17, 397-419) additionally distinguishes the level of strategies for the creation and development of the network level, related to the global economy and

Fig. 1. Synthetic characteristics of the strategy in an enterprise

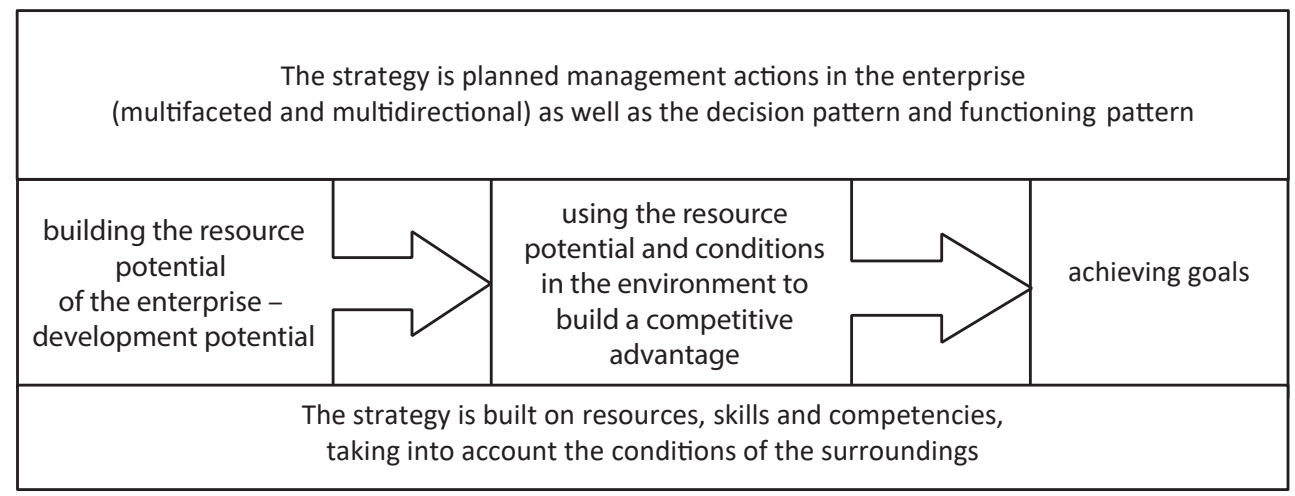

Source: Tobolska (2017: 102) 
the knowledge-based economy. Attention should also be paid to the so-called emergent strategies (according to Kutschker, Schmid, 2005: 808; also Griffin, 2004: 248), which are implemented by enterprises in response to the turbulent environment in the global economy and therefore should be seen as reactions to poor predictability of the implementation of strategic plans.

The fundamental distinction between companies' strategies is related to achieving a competitive advantage. In this respect M.E. Porter (2000: 54) distinguishes three base strategies: cost leadership, differentiation and concentration (cf. also Griffin, 2004: 255-256; Rymarczyk, 2004, 2012a: 317-326; Sowa, 2006: 82-91; Gorynia, 2007: 4145; Romanowska, 2009: 204; Oczkowska, 2013: 180-186). Undertaking competitive strategy is, broadly speaking, the development of existing sources of competitiveness in the enterprise, i.e. resources, skills, structures and other key competencies, as well as creating new ones (Pierścionek, 2003: 275; Sowa, 2006: 79; Kutschker, Schmid, 2005: 798), but also the use of opportunities and evading threats appearing in the environment. Apart from base (Porter's) competitive strategies, other types of them can be found in the literature, e.g. in D. Faulkner and C. Bowman (1996: 28, cf. Sowa, 2006: 87-89; Oczkowska, 2013: 183-186) ), or K. Ohmae (1982: 46-48, cf. op. cit.); in addition a whole range of their types and varieties are presented, among others, by Z. Pierścionek (2011: 204-2016) and K. Obłój (2014: 349-380).

\section{Strategies for the internationalisation of enterprises}

In the case of international enterprises, the distinguished strategies have their specificity and are usually diversified in individual areas (both functional and market areas), or different strategies are applied simultaneously (mixed strategies - Gorynia, 2007: 37-39). Depending on the criterion and aspect of the analysis, they characterise e.g. changes in the position in the international environment (product development strategy, market development, diversification, vertical upward/downward or lateral integration), or the method of allocating its resources on particular foreign markets (strategy of concentration/centration/specialisation, dispersion/decentralisation, or outsourcing/offshoring). Also, strategies in international enterprises are considered on a multi-level basis (Gorynia, 2007: 39; Oczkowska, 2013: 56; Romanowska, 2009: 22):

- at the level of the entire corporation, the strategic orientation of the company is determined, as well as development strategies, which in the case of large multinationals are multi-faceted (from the market or product development), usually mixed and diversified. The development strategies for international enterprises also include strategies for expansion into foreign markets (detailed characteristics of these strategies can be found in the studies of such authors as e.g. Backhaus, Meyer, 1993; Garrette, Dussauge, 1996; Giese, Mossig, Schröder, 2011; Gorczyńska, 2008; Gorynia, 2007; Kraśniak, 2012; Kutschker, Schmid, 2005; Neumair, Schlesinger, Haas, 2012; Pierścionek, 2011; Puślecki, 2009; Rymarczyk, 2004, 2012a, 2012b; Sowa, 2006; Wąsikiewicz-Rusnak, 2005; Zorska, 1998, 2007).

- at the level of strategic units, competition strategies are defined on particular markets, both in the spatial and product dimensions;

- at the level of functional areas of the entire corporation, formulated strategies may include marketing, HR, research and development, financial, controlling, or risk management strategies. 
Due to the way international companies operate, it is worth paying attention to the group of competition strategies, which in this case also have their specificity. J. Rymarczyk (2012b: 321) points out that in the case of international corporations there are changes in the importance of base competition strategies for increasing the flexibility of operation, permanent learning ability, as well as creation of organisational and technical innovations. These complex strategies, according to the cited author, are aimed at adapting enterprises to globalised markets and a knowledge-based economy. In addition, unlike domestic ones, they are based on additional sources of competitive advantages, such as the ability to create international corporate structures and use diverse factors and conditions of production in individual countries or regions of the world (including through practical use of fluctuations in global demand and supply, effective use of exchange rate changes and diversification of tax burdens, as well as economic and customs policy, or through minimising costs and losses resulting from these changes - cf. e.g. Pierścionek, 2011: 35, 152; Sowa, 2006: 82-83; Romanowska, 2009: 111-114). Building a competitive advantage in international corporations is primarily done by locating individual links in the value creation chain on various regional and national markets. This organisational dispersion also allows using large and diverse resources, both tangible and intangible, including strategic, unique skills that allow companies to change their internal configuration towards greater development opportunities permanently, use of critical competencies, knowledge resources and learning, as well as the trademark, patents, known brand or reputation (cf. Kutschker, Schmid, 2005: 806; Sowa, 2006: 75-83; Kulke, 2009: 126). However, the most critical source of the competitive advantage in international corporations seems to be internalisation and the ability to reduce transaction costs - international companies realise internal cross-border flows of enormous scale within their corporate structure, which include streams of investments, technologies, resources, production and sales capacity, components, ready-made products, consultancy, staff, new methods and models (cf. incl. Schamp, 2000; Bathelt, Glückler, 2003: 155; Kulke, 2009: 209; Czupiał, 2011: 53-60; Pierścionek, 2011: 400). Intra-corporate exchange on the international scale is therefore considered by many researchers to be a key factor shaping the competitive position of global enterprises (Sowa, 2006: 82). It is worth emphasising that internalisation has also been reflected in the OLI paradigm of J.H. Dunning in the form of internalisation advantage, while the use of international organisational structures - in the form of a localisation advantage.

In turn, the base competition strategies highlighted by M.E. Porter are difficult to determine on the scale of the entire corporation as it consists of many organisational units dispersed in many markets. Thus, the use of universal sources of the competitive advantage usually focuses on the level of strategic business units and in branches (cf. e.g. Sowa, 2006: 82-91; Gorynia, 2007: 39; Pierścionek, 2011: 18; Oczkowska, 2013: 156). It is also necessary to distinguish between two aspects of the competitive strategy in international enterprises: 1) competition strategies undertaken by subsidiaries on local and regional markets, and 2) strategies at the level of the entire corporation, related to strengthening its competitive position on the international scale, by using local sources of the competitive advantage (localisation advantage) and locating their subsidiaries on foreign markets.

The specialist literature presents quite numerous characteristics of different types of strategies undertaken by multinational enterprises, which can be identified under 
the collective term of an internationalisation strategy (cf. e.g. Kutschker, Schmid, 2005: 809-1038; also Stonehouse, Hamill, Campbell, Purdie, 2001: 93-127; Rymarczyk, 2004: 74; Sowa, 2006: 80-89, 98-118; Stabryła, 2006: 16-21; Gorynia, 2007: 37-45; Romanowska, 2009: 103-107; Zakrzewska-Bielawska, 2009: 340; Neumair, Schlesinger, Haas, 2012: 323-385; Oczkowska, 2013: 152-186). Although there are various ways of approaching the issue of the internationalisation strategy, their essence consists in distinguishing those company strategies that relate to activities on foreign markets and involvement in various economic operations with foreign partners in order to gain and maintain a competitive advantage (Rymarczyk, 2004: 74; Stabryła, 2006: 17; Gorynia, 2007: 35; Oczkowska, 2013: 155). Internationalisation strategies thus reflect how enterprises operate in an international environment through the characteristic (specific to the domestic market) ways of shaping their internal structure and functioning on international markets (cf. Urbanowska-Sojkin, 1996: 24; Rymarczyk, 2004: 74). The internationalisation strategy can also be considered as one of the forms of a development strategy of an international enterprise, which follows spatial expansion outside the home country, but also through the diversification of products offered on various foreign markets ("active internationalisation" by Gorynia, 2007: 35; also Fonfara, 2009: 12), or establishing economic relations with foreign economic entities ("passive internationalisation", op. cit.). According to M. Gorynia (op. cit.), at the level of the whole company one can talk about internationalisation when at least one product in the company's portfolio is connected with the foreign market, and in very diverse forms, i.e. from non-capital cooperation, through, for instance, strategic alliances and exports, to independent production abroad.

Undertaking internationalisation strategies, according to M. Kutschker and S. Schmid (2005: 809-810), depends on a certain philosophy and vision of the company's operation and its organisational culture. Therefore, what strategy an international company takes depends on certain values, attitudes, orientations and visions of the future of its owners and management (cf. also Griffin, 2004: 248-249). The quoted authors indicate that decisions regarding the selection of internationalisation strategies stem from some of the original, basic assumptions of the company's operation, which can be identified and recognised on the basis of strategic orientations adopted by them. There are many model concepts that describe strategic orientations; the best known include the multi-stage concept of H. Perlmutter (1969, its detailed presentation can be found in the papers of, for example, M. Kutscher and S. Schmid of 2005: 279-289, also in the studies by J. Rymarczyk of 2004 and 2012, and M. Wdowicka of 2005), as well as a multi-level concept of strategic orientation types of C.A. Bartlett and S. Ghoshal (1987a, 1987b), onestage concepts (after Kutschker, Schmid, 2005: 279-289): "heterarchy" by G. Hedlund (1986), "diversified multinational corporation" by C.K. Prahalad and Y.L. Doz (1991), and "horizontal organisation" by R.E. White and T.A. Poynter (1989). Therefore, it can be assumed that strategic orientations reflect a certain general pattern of internationalisation (Internationalisierungsmuster, according to Kutschker, Schmid, 2005: 278; see also Gorynia, 2007: 37; Urbanowska-Sojkin, 1996; Oczkowska, 2013), and thus the primary and basic internationalisation strategy at the level of the entire corporation. In the case of large international corporations with extensive organisational and spatial structures, it becomes an important issue to define their overall strategies (corporate strategies or basic strategies, cf. Stabryła, 2006: 54-55; Gorynia, 2007: 37), related to the undertaken internationalisation processes, both through expansion into foreign 
markets and through their involvement in various business operations with foreign partners. Other types of strategies (e.g. business unit strategies, competition strategies, functional strategies) can be considered as lower-level strategies that are usually strongly diversified at the level of the entire corporation and concern only selected areas or functional levels, thus they do not characterise the overall internationalisation strategy of a big and diversified international enterprise.

\section{Strategic orientations of international enterprises - the model approach of C.A. Bartlett and S. Ghoshal}

In the multistage concept of C.A. Bartlett and S. Ghoshal (1987a, 1987b) the authors distinguish four types of strategic orientation: international, multinational, global, and transnational (see also: Zorska, 1998: 155-180; Kutschker, Schmid, 2005: 290; Sowa, 2006: 92-98; Tobolska, 2006: 126-130; Rymarczyk, 2012b: 527-536; Neumair, Schlesinger, Haas, 2012: 307-310; Oczkowska, 2013: 161-169; Dicken, 2015: 138140). Each of the mentioned types of strategic orientations represents different ways of managing, configuring the organisational structure, the role of foreign branches and the scope of their coordination and integration of activities, the degree of centralisation, the scope of key skills and competencies in individual organisational units, and the importance of organisational culture in building the company's identity (see Tab. 1). The distinguished features, mainly of a qualitative nature, are to facilitate the recognition of the internationalisation level of an international enterprise: from the weakest in the case of strategic international orientations, to the strongest in the case of transnational strategies. The concept of C.A. Bartlett and S. Ghoshal is therefore a qualitative approach to enterprise internationalisation processes and is based on an in-depth analysis and understanding of the main aspects of management - formulating strategies, shaping the organisational structure, coordinating activities and the characteristics of the entire organisation. As indicated earlier, the four presented model strategic orientations can be used to identify comprehensive internationalisation strategies for international enterprises. a detailed description of each type of strategic orientation was presented by such authors as, for example, Zorska (1998), Stonehouse, Hamill, Campbell, Purdie (2001), Kutschker, Schmid (2005), Sowa (2006), Gorynia (2007), Neumair, Schlesinger, Haas (2012), Rymarczyk (2012b), Oczkowska (2013), Dicken (2015), Tobolska (2017). At this point it should also be noted that the term "strategic orientations" is used interchangeably with such terms as "strategies of transborder competition" (Sowa, 2006: 92), "competition strategies of supranational corporations" (Pierścionek, 2011: 354, 370), "strategic orientations of internationalisation and globalisation of enterprises" (Rymarczyk, 2012b: 262-264), "organisation models/forms/types of international enterprises" (Neumair, Schlesinger, Haas, 2012: 307-309; Dicken, 2015: 138-141), "figures/patterns of internationalisation of enterprise" or "archetypes of organisations" (Kutschker, Schmid, 2005: 278 et seq.), as well as "supranational/transborder corporate strategies" (Zorska, 1998: 155-164; Zorska, 2002: 95-109). In the present study the term "strategic orientations" is used. It is treated as a synonym of comprehensive internationalisation strategies of international enterprises, whose synthetic characteristics are presented in Tab. 1. 
Tab. 1. Types of strategic orientations of companies operating on international markets (according to the concept of C.A. Bartlett and S. Ghoshal)

\begin{tabular}{|c|c|c|c|c|}
\hline $\begin{array}{c}\text { Type of } \\
\text { strategic } \\
\text { orientation }\end{array}$ & International & Multinational & Global & Transnational \\
\hline $\begin{array}{l}\text { The original } \\
\text { aspect of type } \\
\text { distinction }\end{array}$ & $\begin{array}{l}\text { Transfer of mother } \\
\text { technologies to } \\
\text { other markets } \\
\text { and their local } \\
\text { responsiveness }\end{array}$ & $\begin{array}{l}\text { Diversification } \\
\text { of services/products } \\
\text { corresponding to } \\
\text { the requirements of } \\
\text { local markets }\end{array}$ & $\begin{array}{l}\text { Cost-effective and } \\
\text { export-oriented } \\
\text { competitive position }\end{array}$ & $\begin{array}{l}\text { Diversity, } \\
\text { standardisation and } \\
\text { transfer }\end{array}$ \\
\hline $\begin{array}{l}\text { Key } \\
\text { competencies }\end{array}$ & $\begin{array}{l}\text { Ability to innovate } \\
\text { and transfer } \\
\text { knowledge }\end{array}$ & $\begin{array}{l}\text { Ability to react to } \\
\text { local differences }\end{array}$ & $\begin{array}{l}\text { Ability to integrate } \\
\text { activities on a global } \\
\text { scale }\end{array}$ & $\begin{array}{l}\text { Ability to innovate } \\
\text { and integrate }\end{array}$ \\
\hline $\begin{array}{l}\text { Development } \\
\text { and knowledge } \\
\text { diffusion }\end{array}$ & $\begin{array}{l}\text { Creating knowledge } \\
\text { in the head office } \\
\text { and its transfer to } \\
\text { branches abroad }\end{array}$ & $\begin{array}{l}\text { Creating and } \\
\text { providing } \\
\text { knowledge in every } \\
\text { organisational unit }\end{array}$ & $\begin{array}{l}\text { Creating and } \\
\text { providing } \\
\text { knowledge in the } \\
\text { head office }\end{array}$ & $\begin{array}{l}\text { Joint development } \\
\text { and use of } \\
\text { knowledge }\end{array}$ \\
\hline $\begin{array}{l}\text { Role of foreign } \\
\text { branches }\end{array}$ & $\begin{array}{l}\text { Adjusting } \\
\text { and applying } \\
\text { competencies from } \\
\text { the head office }\end{array}$ & $\begin{array}{l}\text { Recognition and } \\
\text { use of local market } \\
\text { opportunities }\end{array}$ & $\begin{array}{l}\text { Transfer of } \\
\text { strategies from the } \\
\text { head office }\end{array}$ & $\begin{array}{l}\text { Diversified } \\
\text { participation of } \\
\text { local units (e.g. } \\
\text { strategic leaders) } \\
\text { in integrated global } \\
\text { operations } \\
\end{array}$ \\
\hline $\begin{array}{l}\text { Configuration } \\
\text { of values and } \\
\text { skills }\end{array}$ & $\begin{array}{l}\text { Key competencies } \\
\text { centralised, others } \\
\text { decentralised }\end{array}$ & $\begin{array}{l}\text { Decentralised and } \\
\text { independent within } \\
\text { countries }\end{array}$ & $\begin{array}{l}\text { Centralised and } \\
\text { oriented to the } \\
\text { global market }\end{array}$ & $\begin{array}{l}\text { Distributed, } \\
\text { interdependent and } \\
\text { specialised }\end{array}$ \\
\hline $\begin{array}{l}\text { Configuration } \\
\text { and } \\
\text { coordination of } \\
\text { activities } \\
\text { (cf. Fig. 3.3) }\end{array}$ & $\begin{array}{l}\text { Coordinated } \\
\text { federation, } \\
\text { completion, } \\
\text { extension of the } \\
\text { head office's } \\
\text { activities (b) } \\
\end{array}$ & $\begin{array}{l}\text { Decentralised } \\
\text { federation (a) }\end{array}$ & $\begin{array}{l}\text { Centralised node } \\
\text { structure - branches } \\
\text { as supply channels } \\
\text { to foreign markets } \\
\text { (c) }\end{array}$ & $\begin{array}{l}\text { Integrated } \\
\text { network- branches } \\
\text { in the integrated } \\
\text { system, functional } \\
\text { heterarchy (d) }\end{array}$ \\
\hline $\begin{array}{l}\text { Structure } \\
\text { diversity }\end{array}$ & $\begin{array}{l}\text { Divisional (product/ } \\
\text { geographical) }\end{array}$ & $\begin{array}{l}\text { Geographical } \\
\text { (regions, countries) }\end{array}$ & $\begin{array}{l}\text { Global (groups } \\
\text { of products) }\end{array}$ & $\begin{array}{l}\text { Matrix (groups of } \\
\text { products/countries, } \\
\text { regions) }\end{array}$ \\
\hline $\begin{array}{l}\text { Connections/ } \\
\text { flows }\end{array}$ & $\begin{array}{l}\text { Mainly } \\
\text { unidirectional } \\
\text { (resources, } \\
\text { information, goods) }\end{array}$ & $\begin{array}{l}\text { Unidirectional } \\
\text { (resources, supply) }\end{array}$ & $\begin{array}{l}\text { Unidirectional } \\
\text { (resources, } \\
\text { information, goods) }\end{array}$ & $\begin{array}{l}\text { Multidirectional } \\
\text { (network-related, } \\
\text { resources, } \\
\text { information, goods) }\end{array}$ \\
\hline $\begin{array}{l}\text { Organisation } \\
\text { culture }\end{array}$ & Quite important & Not very important & Important & Very important \\
\hline Base strategy & Product-diversified & $\begin{array}{l}\text { Diversified } \\
\text { geographically }\end{array}$ & Cost-related & $\begin{array}{l}\text { Comprehensive: } \\
\text { geographically and } \\
\text { product diverse and } \\
\text { cost-related }\end{array}$ \\
\hline
\end{tabular}

Source: own work based on Bartlett, Ghoshal (1987a, 1987b), Zorska (1998), Kutschker, Schmid (2005: 289298, 1034-1036), Neumair, Schlesinger, Haas (2012: 307-309), also Tobolska (2017: 112)

It should be emphasised that in the presented concept of C.A. Bartlett and S. Ghoshal, the basic dimensions of internationalisation, i.e. the configuration of the organisational structure and the coordination of activities on international markets, also indicate the critical geographical dimension of internationalisation processes. It is, in the first place, that the spatial differentiation of the location of organisational units (configuration) determines the degree of internationalisation of the enterprise, and thus belongs 
Fig. 2. Models of coordination and configuration of international enterprises by adopted strategic orientation (according to the concept of C.A. Bartlett and S. Ghoshal)

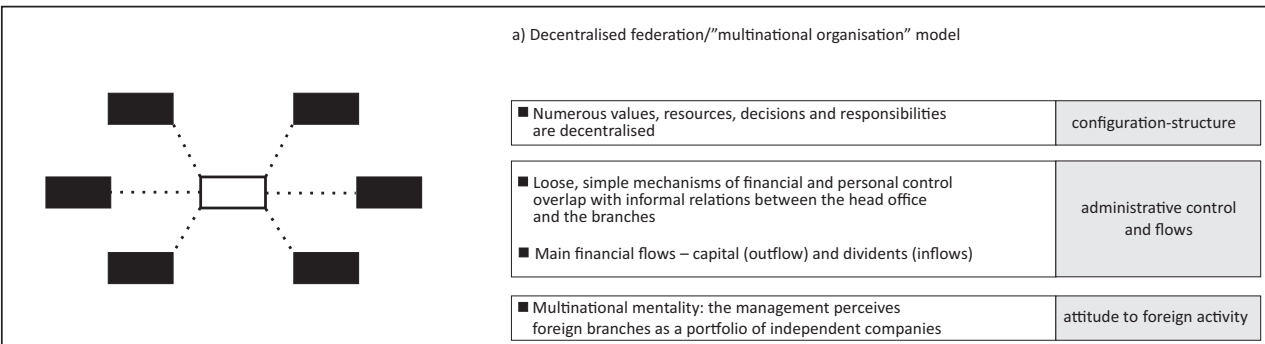

b) Coordinated federation/"international organisation" model

\begin{tabular}{|c|c|}
\hline configuration-structure & $\begin{array}{l}\text { Many of the values, resources, decisions and responsibilities } \\
\text { are decentralised but coordinated by the parent company }\end{array}$ \\
\hline $\begin{array}{l}\text { administrative control } \\
\text { and flows }\end{array}$ & $\begin{array}{l}\text { Formal control and planning mechanisms conducted } \\
\text { by the management of the corporation enable tight relationships } \\
\text { between the parent company and its branches } \\
\text { Mainly knowledge, technology, products, } \\
\text { processes and systems flows }\end{array}$ \\
\hline attitude to foreign activity & $\begin{array}{l}\text { International mentality: the management perceives foreign } \\
\text { branches as "satellites" of the parent company }\end{array}$ \\
\hline
\end{tabular}

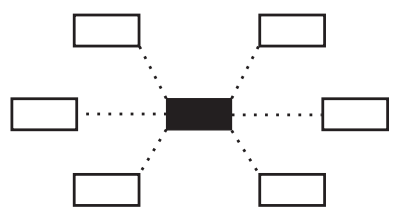

c) Centralised, node structure/"global organisation" model

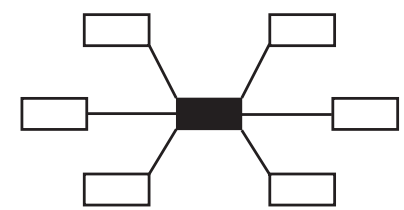

\begin{tabular}{|l|l|}
\hline $\begin{array}{l}\text { The parent company is a node most of the strategic values, } \\
\text { resources, decisions and responsibilities are centralised }\end{array}$ & configuration-structure \\
\begin{tabular}{|l|l|}
\hline $\begin{array}{c}\text { Simple control mechanisms centrally taken strategic decisions, } \\
\text { control of operation, decisions, resources and information }\end{array}$ & $\begin{array}{c}\text { administrative control } \\
\text { and flows }\end{array}$ \\
Mainly flows of goods & Moor
\end{tabular}
\end{tabular}

- Global mentality: the management perceives foreign branches

as supply channels of the unified global market

d) Integrated network model/"transnational organisation" model

\begin{tabular}{|c|c|}
\hline configuration-structure & $\begin{array}{c}\text { Dispersion of specialist resources, skills, } \\
\text { decisions and responsibilities }\end{array}$ \\
\hline $\begin{array}{c}\text { administrative control } \\
\text { and flows }\end{array}$ & $\begin{array}{c}\text { Complex processes of cooperation and coordination } \\
\text { when making joint decisions }\end{array}$ \\
\hline attitude to foreign activity & $\begin{array}{c}\text { Integrated network of interdependent units involved in significant } \\
\text { components, products, resources and information flows }\end{array}$ \\
\hline
\end{tabular}

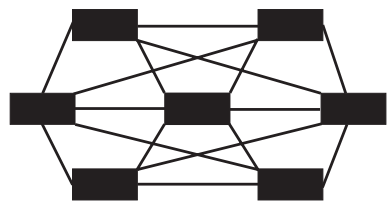

Source: own work based on Stonehouse, Hamill, Campbell, Purdie (2001: 257), Kutschker, Schmid (2005: 292, 1035), Rymarczyk (2012b: 527-530), Dicken (2015: 138-139) 
to one of the distinct types of strategic orientations. The configuration dimension refers to the degree of scattering or spatial concentration of individual, organisational units that are the links of the value-added chain in international companies (Kutschker, Schmid, 2005: 970; also Stonehouse, Hamill, Campbell, Purdie, 2001: 45). In this dimension, locating various activities in different places depends on the possibility of gaining a competitive advantage that individual locations offer, and consequently depends on the location factors. In turn, the coordination dimension indicates the scope of mutual adjustment and harmonisation of spatially distributed functions, located in many countries, to gain a competitive advantage. According to Stonehouse, Hamill, Campbell, Purdie (2001: 45) "coordination includes information sharing, responsibility in allocation and organisation of activities". In the concept presented, the authors distinguish four different coordination models, which they attribute to four strategic orientations:

- coordinated federation in international enterprises,

- decentralised federation in multinational enterprises,

- centralised node structure in global enterprises,

- integrated network structure in transnational enterprises.

The distinguished models indicate differentiated relations between organisational units depending on the degree of centralisation and control of decisions, and the flow of resources, which are graphically presented in Fig. 2.

Characterising the "archetypes" of international enterprises of C.A. Bartlett and S. Ghoshal, attention should also be paid to a slightly different perspective of their analysis in two profiles at the same time: on the one hand, due to the benefits of global integration and standardisation, and on the other due to the benefits of adapting to local market conditions. These are two independent dimensions that differentiate the distinguished archetypes of enterprises, which can be expressed in the form of a dichotomous arrangement, shown in Fig. 3.

Fig. 3. Advantages of global integration and local responsiveness in strategic orientations of international enterprises

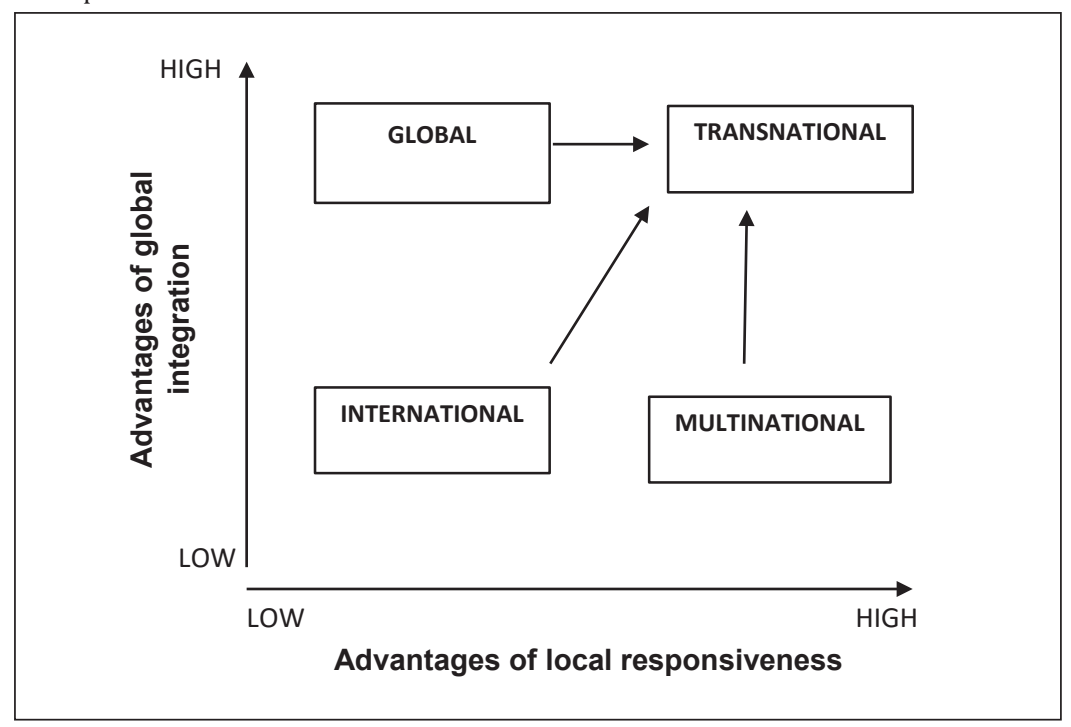

Source: Tobolska (2017: 115) 
J. Fayerweather described these two multidirectional aspects of the functioning of international enterprises (1969, after Neumair, Schlesinger, Haas, 2012: 305-307). At the end of the 1960s he proposed a two-dimensional analysis in the area of the impact of two strong tendencies - global integration and local responsiveness. This concept is known in the theory of international management as the so-called I-R paradigm (integration-reaction paradigm), which describes the fundamental management problem in international enterprises, concerning the conflicting requirements between global integration and adaptation to local needs and markets (op. cit). According to the cited authors, there are no unambiguous interpretations of both dimensions, and there are several variants of using the I-R paradigm to describe directly observed facts from the activities of international enterprises. However, in general terms, the integration dimension indicates the degree of demand for a global strategy or integrated business system, while the reactivity dimension (reactiveness, adaptation) describes the degree of reflection of conditions specific to a given economic space in the activities of international enterprises, in particular in the form of applied international marketing tools and adapting the product offer.

P. Dicken also presents analogous relationships (Dicken, 1998: 207, 2015: 129) based on the development of C.K. Prahalad and Y.L. Doz from 1987, as well as A. Zorska (1998: 90-91, 155-156; see also Romanowska, 2009: 105; Pierścionek, 2011: 371) based on the findings of Ch. Hill and G.R. Jones from 1995. In this approach, the type of transborder strategies depends on the relationship between the pressure to reduce unit costs of products and the pressure to adapt products to the needs of local/national markets. International corporations have great opportunities to reduce costs by locating their functions in optimal economic conditions, offered by various national markets, as well as by increasing scale, specialisation and standardisation - including these aspects characterise the benefits of global integration of spatially dispersed production and organisational functions. Cost reduction must be accompanied by the growing integration of activities carried out by various corporate entities operating in many countries. At the same time, some functions must be adapted to the capabilities and needs of local markets. The local adjustment also involves foreign subsidiaries taking decisions in the field of resource management, in response to the needs of buyers and the requirements of the competitive situation on the domestic market (after Zorska, 1998: 91).

It seems that the research perspective described in the I-R paradigm is particularly useful for research objectives realised in the field of geography of enterprise.

\section{SUMMARY}

Summarising considerations on the strategy of international enterprises, it should be noted that this is a very complex and multithreaded issue. It applies to very different ways of classifying strategies, and different areas and levels of enterprises. Moreover, many approaches represent different research trends (e.g. strategic management, internationalisation and globalisation of enterprises, international business and foreign expansion, enterprise competitiveness, as well as geography of enterprise). An additional difficulty is also posed by the interpretation and definition of individual terms, because researchers addressing these issues accentuate different views of the issues presented. Depending on the purpose of study, the same issues are often discussed under different names (for example, the forms of expansion into foreign markets are presented 
as "entry strategies on the foreign market" in the studies of J. Rymarczyk (2012a) and A. Zorska (1998), as "market service strategies" according to G. Stonehouse, J. Hamill, D. Campbell, T. Purdie (2001), as "expansion strategies of transnational corporations" according to K. Sowa (2006), or as "forms of entry of enterprises into foreign markets" according to R. Oczkowska (2013).

The issue of international business strategy considered in the study, taking into account their spatial aspects, makes it possible to see the fundamental problems of economic geography, including its current of geography of enterprise, in the new context of innovation, competition and the global network economy. It also seems to be an essential step in explaining phenomena and processes of the socio-economic development, their spatial diversity and interdependence.

\section{References}

Ansoff, H.I. (1957). Strategies for Diversification. Harvard Business Review, 35(5), 113-124.

Backhaus, K., Meyer, M. (1993). Strategische Allianzenund strategische Netzwerke. Wirtschsaftwissenschaftliches Studium, 22(7), 330-334.

Bartlett, C.A., Goshal, S. (1987a). Managing Across Borders: New Strategic Requirements. Sloan Management Review, 28(4), 7-17.

Bartlett, C.A., Goshal, S. (1987b). Managing Across Borders: New Organizational Responses. Sloan Management Review, 29(1), 43-53.

Bathelt, H., Glückler, J. (2003). Wirtschaftsgeographie [Economic geography]. Stuttgart: Verlag Eugen Ulmer.

Boguś, M. (2012). Koncentracja przestrzenna działalności gospodarczej korporacji ponadnarodowej Google w latach 2006-2010 [Spatial concentration of the economic activity of the multinational corporation Google in years 2006-2010]. Prace Komisji Geografii Przemysłu Polskiego Towarzystwa Geograficznego [Studies of the Industrial Geography Commission of the Polish Geographical Society], 20, 40-53.

Bonar, P. (2011). Funkcjonowanie korporacji Ericsson w warunkach globalnego kryzysu gospodarczego. [Functioning of Ericsson company in the conditions of global economic crisis]. Prace Komisji Geografii Przemysłu Polskiego Towarzystwa Geograficznego [Studies of the Industrial Geography Commission of the Polish Geographical Society], 17, 197-212.

Banaszyk, P. (2002). Podstawy organizacji i zarzq̨dzania [Fundamentals of organization and management]. Poznań: Wyższa Szkoła Handlu i Rachunkowości w Poznaniu.

Brezdeń, P. (2004). Wpływ bezpośrednich inwestycji zagranicznych na rozwój regionalnej i lokalnej przestrzeni gospodarczej w województwie dolnośląskim. [Impact of foreign direct investment on the development of regional and local economic space in the Dolnośląskie Voivodeship]. Biuletyn Komitetu Przestrzennego Zagospodarowania Kraju Polskiej Akademii Nauk [Bulletin of the National Spatial Development Committee of the Polish Academy of Sciences], 211, 499-518.

Brezdeń, P. (2006). Uwarunkowania bezpośrednich inwestycji zagranicznych i ich wpływ na umiędzynarodowienie działalności gospodarczej w województwie dolnośląskim [Conditions of foreign direct investment and their impact on the internationalization of economic activity in the Lower Silesian Voivodeship]. Prace Komisji Geografii Przemysłu Polskiego Towarzystwa Geograficznego [Studies of the Industrial Geography Commission of the Polish Geographical Society], 8, 60-74.

Brezdeń, P. (2016). Wybrane aspekty wpływu kapitału zagranicznego na gospodarkę Dolnego Śląska - ujęcie przestrzenne. [Selected Aspects of the Influence of Foreign Capital on the

Lower Silesia Economy - a Spatial Perspective]. Prace Komisji Geografii Przemysłu Polskiego Towarzystwa Geograficznego [Studies of the Industrial Geography Commission of the Polish Geographical Society], 30(2), 55-71.

Chandler, A.D. (1962). Strategy and Structure. Chapters in the History of the Industrial Enterprise. Cambridge, Massachusetts: The M.I.T. Press. 
Cieślik, A. (2005). Geografia inwestycji zagranicznych. Przyczyny i skutki lokalizacji spółek z udziałem kapitału zagranicznego w Polsce [Geography of foreign investments. Causes and effects of the location of companies with foreign capital in Poland]. Warszawa: Wydawnictwo Uniwersytetu Warszawskiego.

Cieślik, A. (2013). Multinational firms and international fragmentation of production: The case of Poland. International Journal of Economic Research, 10(2), 219-233.

Clark, G. L., Wrigley, N. (1997). Exit, the firm and sunk costs: Reconceptualizing the corporate geography of disinvestment and plant closure. Progress in Human Geography, 21, 338-358.

Cyrson, E. (2009). Przedsiębiorstwo w otoczeniu wpół zglobalizowanym [An enterprise in a semi-globalized environment]. In: O. Dębicka, A. Oniszczuk-Jastrząbek, T. Gutowski, J. Winiarski J. (ed.). Przedsiębiorstwo w otoczeniu globalnym [Enterprise in a global environment]. Gdańsk: Fundacja Rozwoju Uniwersytetu Gdańskiego, 45-58.

Czupiał, J. (2011). Przedsiębiorstwo międzynarodowe [International enterprise]. Wrocław: Wydawnictwo Uniwersytetu Ekonomicznego we Wrocławiu.

Defever, F. (2006). Functional Fragmentation and the Location of Multinational Firms in Enlarged Europe. Regional Science and Urban Economics, 36(5), 658-677.

Defever, F. (2012). The Spatial Organization of Multinational Firms. Canadian Journal of Economics, 45(2), 672-697.

Dicken, P. (1990). The geography of Enterprise. Elements of a Research Agenda. In: M. Smidt, E. Wever (ed.). The Corporate Firm in a Changing World Economy. Case Studies in the Geography of Enterprise. London: Routledge, 234-244.

Dicken, P. (1998). Global Shift: Transforming the World Economy. London: Chapman.

Dicken, P. (2015). Global Shift. Mapping the Changing contours of the world economy. SAGE.

Domański, B. (1997). Geografia przedsiębiorstw - niedoceniany nurt badań w polskiej geografii ekonomicznej [Geography of enterprise - an undervalued research trend in Polish economic geography]. W: B. Domański, A. Jackowski (ed.). Geografia, człowiek, gospodarka [Geography, man, economy]. Kraków: Wydawca Instytut Geografii Uniwersytetu Jagiellońskiego, 101114.

Domański, B. (2001). Kapitał zagraniczny w przemyśle Polski. Prawidłowości rozmieszczenia, uwarunkowania i skutki [Foreign capital in the Polish industry. Distribution patterns, conditions and effects]. Kraków: Wydawca Instytut Geografii i Gospodarki Przestrzennej Uniwersytetu Jagiellońskiego.

Domański, B. (2002). Problemy metod badań inwestycji zagranicznych w układach przestrzennych [Problems of research methods on foreign investments in spatial systems]. W: H. Rogacki (ed.). Możliwości i ograniczenia zastosowań metod badawczych w geografii społeczno-ekonomicznej i gospodarce przestrzennej [Possibilities and limitations of applications of research methods in the socio-economic geography and spatial management]. Poznań: Bogucki Wydawnictwo Naukowe, 197-207.

Domański, B. (2005). Transnational Corporation and the postsocialist economy. Learning the rapes and forging new relationships in contemporary Poland. In: C. Alvstan, E. Schamp (ed.). Linking industries across the World: Processes of Global Networking. Aldershat: Ashgate, 147-172.

Domański, B. (2011). Foreign capital and the development of Polish regions. Czasopismo Geograficzne [Geographical Journal], 82(1-2), 17-187.

Domański, B., Gwosdz, K., Huculak, M., Wiedermann, K. (2005). Oddziaływanie SSE Euro-Park Mielec na otoczenie lokalne. Powiązania firm i efekty mnożnikowe [The impact of the Euro-Park Mielec SEZ on the local environment. Business links and multiplier effects]. In: Dziesięć lat doświadczeń pierwszej specjalnej strefy ekonomicznej Mielec 1995-2005 [Ten years of experience of the first Special Economic Zone in Mielec 1995-2005]. Kraków: Instytut Geografii i Gospodarki Przestrzennej Uniwersytetu Jagiellońskiego.

Doz, Y.L, Prahalad, C.K. (1991). Managing DMNCs: A Searchfor a New Paradigm. In: Strategic Management Journal 12 Jg. Special Issue, 145-164.

Dziemianowicz, W. (1997). Kapitał zagraniczny a rozwój lokalny i regionalny w Polsce [Foreign capital versus local and regional development in Poland]. Studia Regionalne i Lokalne [Regional and Local Studies], 20(53). 
Faulkner, D., Bowman, C. (1996). Strategie konkurencji [Competition strategies]. Warszawa: Wydawnictwo Gebethner \& Spółka.

Fayerweather, J. (1969). International Business Management. a Conceptual Framework. New York.

Fonfara, K. (ed.) (2009). Zachowania przedsiębiorstw $w$ procesie internacjonalizacji [Behaviour of enterprises in the internationalisation process]. Warszawa: Polskie Wydawnictwo Ekonomiczne.

Fonfara, K., Gorynia, M., Najlepszy, E., Schroeder, J. (2000). Strategie przedsiębiorstw w biznesie międzynarodowym [Strategies of enterprises in international business]. Poznań: Akademia Ekonomiczna.

Frigant, V., Layan, J.-B. (2009). Modular production and the new division of labour within Europe: The perspective of French automotive parts suppliers. European Urban and Regional Studies, $16,11-25$.

Garrette, B., Dussauge, P. (1996). Strategie aliansów na rynku [Alliance strategies on the market]. Warszawa: Poltext.

Gierańczyk, W., Stańczyk, A. (2003). Korporacje międzynarodowe w przestrzeni globalnej [International corporations in global space]. Prace Komisji Geografii Przemysłu Polskiego Towarzystwa Geograficznego [Studies of the Industrial Geography Commission of the Polish Geographical Society], 5, 73-85.

Giese, E., Mossig, I., Schröder, H. (2011). Globalisierung der Wirtschaft. Eine wirtschaftsgeographische Einführung [Globalisation of the economy. An economic geography introduction]. Paderborn:Verlag Schöningh.

Gorczyńska, A. (2008). Międzynarodowa ekspansja przedsiębiorstw. W poszukiwaniu źródeł wzrostu wartości rynkowej [International expansion of enterprises. In search of sources of growth in market value]. Warszawa: CeDeWu Wydawnictwa Fachowe.

Gorynia, M. (2007). Strategie zagranicznej ekspansji przedsiębiorstw [Strategies of foreign expansion of enterprises]. Warszawa: Polskie Wydawnictwo Ekonomiczne.

Gorynia, M., Samelak, O. (2013). Przegląd badań nad funkcjonowaniem filii korporacji transnarodowych w Polsce [Review of research on the operation of the branches of transnational corporations in Poland]. Gospodarka Narodowa [National Economy] 10(266), 69-91.

Griffin, R.W. (2004). Podstawy zarzadzania organizacjami [Basics of organisation management]. Warszawa: Wydawnictwo Naukowe PWN.

Hardy, J. (2002). Cultural embeddedness, corporate strategy and foreign investment in Poland: a tale of two firms. In: R. Hayter, R. LeHeron (ed.). Knowledge, industry and the environment: Institutions and innovation in territorial perspective. London: Ashgate, 273-87.

Hatch, M.J. (2002). Teoria organizacji [Theory of organisation]. Warszawa: Wydawnictwo Naukowe PWN.

Hedlund, G. (1986). The Hypermodern MNC - a Heterarchy. Human Resources Management, 25(1), 9-35.

Holm, U., Malmberg, A., Sölvell, O. (2003). Subsidiary impact on host-country economies - The case of foreign-owned subsidiaries attracting investment into Sweden. Journal of Economic Geography, 3, 389-408.

Ivarsson, I., Johnsson, T. (2003). Local technological competence and asset-seeking FDI: An empirical study of manufacturing and wholesale affiliates in Sweden. International Business Review, 12, 369-86.

Jeżak, J. (1993). Zarządzanie przyszłością czyli strategia przedsiębiorstwa [Managing the future or enterprise strategy]. In: Z. Mikołajczyk (ed.). Jak zarządzać przedsiębiorstwem w gospodarce rynkowej [How to manage a company in a market economy]. Warszawa: Wydawnictwo Naukowe PWN, 33-54.

Jones, A. (2005). Truly global corporations? Theorising organisational globalisation in advanced business services. Journal of Economic Geography, 5, 177-200.

Kilar, W. (2011). Wpływ kryzysu na funkcjonowanie korporacji Panasonic [The impact of the crisis on the functioning of Panasonic corporation]. Prace Komisji Geografii Przemystu Polskiego Towarzystwa Geograficznego [Studies of the Industrial Geography Commission of the Polish Geographical Society], 17, 187-196. 
Kilar, W. (2014). Spatial Concentration of IT Corporation Headquarters. Prace Komisji Geografii Przemystu Polskiego Towarzystwa Geograficznego [Studies of the Industrial Geography Commission of the Polish Geographical Society], 25, 56-80.

Kostrubiec, B. (2006). Delokalizacja przedsiębiorstw - przejaw światowej samoregulacji [Relocation of enterprises - a manifestation of global self-regulation]. Prace Komisji Geografii Przemysłu Polskiego Towarzystwa Geograficznego [Studies of the Industrial Geography Commission of the Polish Geographical Society], 8, 37-47.

Koźmiński, A., 1999. Zarządzanie międzynarodowe [International management]. Warszawa: Polskie Wydawnictwo Ekonomiczne.

Kraśniak, J. (2012). Zmiany struktur organizacyjnych przedsiębiorstw $w$ procesie internacjonalizacji [Changes in the organisational structures of enterprises in the internationalisation process]. Poznań: Wydawnictwo Uniwersytetu Ekonomicznego w Poznaniu.

Kreikebaum, H. (1996). Strategiczne planowanie w przedsiębiorstwie [Strategic planning in an enterprise]. Warszawa: Wydawnictwo Naukowe PWN.

Krumme, G. (1969). Towards a Geography of Enterprise. Economic Geography, 45, 30-40.

Kulke, E. (2009). Wirtschaftsgeographie [Economic geography]. Paderborn: Schöningh Verlag.

Kutschker, M, Schmid, S. (2005). Internationales Management [International management]. Múnchen, Wien: R. Oldenbourg Verlag.

Lizak, P. (2009). Wpływ koncernu Fiat na kształtowanie się przemysłu samochodów osobowych w Polsce. [Influence of the FIAT concern on the shaping of the Polish automobile industry]. Prace Komisji Geografii Przemysłu Polskiego Towarzystwa Geograficznego [Studies of the Industrial Geography Commission of the Polish Geographical Society], 12, 63-78.

Maskell, P. (2001). The firm in economic geography. Economic Geography, 77, 329-44.

Matykowski, R., Tobolska, A. (2006). Działalność przemysłowa w warunkach wzrastającej internacjonalizacji i globalizacji na przykładzie wybranych produktów. [Industrial activity in the conditions of increasing internationalisation and globalisation on the example of selected products]. Prace Komisji Geografii Przemysłu Polskiego Towarzystwa Geograficznego [Studies of the Industrial Geography Commission of the Polish Geographical Society], 8, 47-59.

Matykowski, R., Tobolska, A. (2009). Funkcjonowanie zakładów przemysłowych XXI wieku na przykładzie Swedwood Poland i Volkswagen Motor Polska: analiza dojazdów do pracy [Operation of 21st-century industrial plants as exemplified by Swedwood Poland and Volkswagen Motor Polska Sp. z o.o.: Analysis of journeys to work]. Prace Komisji Geografii Przemysłu Polskiego Towarzystwa Geograficznego [Studies of the Industrial Geography Commission of the Polish Geographical Society], 14, 65-75.

McNee, R.B. (1960). Toward a More Humanistic Economic Geography: The Geography of Enterprise. Tijdschrift voor Economische en Sociale Geografie, 51, 201-2015.

Mintzberg, H., Quinn, J.B. (1991). The Strategy Process. Concepts, Contexts, Cases. Englewood Cliffs, New Jersey: Second Edition. Prentice-Hall Inc.

Neumair, S.M., Schlesinger, D.M., Haas, H-D (2012). Internationale Wirtschaft. Unternehmen und Weltwirtschaftsraum im Globalisierungsprozess [International economy. Business and global economic space in the globalisation process]. München: Oldenbourg Verlag.

Obłój, K. (1993). Strategia sukcesu firmy [Company's success strategy]. Warszawa: Polskie Wydawnictwo Ekonomiczne.

Obłój, K. (2014). Strategia organizacji [Strategy oforganisation]. Warszawa: Polskie Wydawnictwo Ekonomiczne.

Oczkowska, R. (2013). Międzynarodowa ekspansja przedsiębiorstw $w$ warunkach globalizacji. Motywy - Strategie - Tendencje [International expansion of enterprises in the conditions of globalisation. Motives - Strategies - Trends]. Warszawa: Difin.

Ohmae, K. (1982). The Mind of the Strategist. New York: McGraw-Hill.

Pakulska, T. (2010). Bezpośrednie inwestycje zagraniczne a rozwój przedsiębiorczości w regionie [Foreign direct investment and the development of entrepreneurship in the region]. In: K. Kuciński (ed.). Przedsiębiorczość a rozwój regionalny w Polsce [Entrepreneurship and regional development in Poland]. Warszawa: Difin, 153-209.

Pavlínek, P. Domański, B., Guzik R. (2009). Industrial upgrading through foreign direct investment in Central European automotive manufacturing. European Urban and Regional Studies, $16,43-63$. 
Perlmutter, H.V. (1969). The Tortuous Evolution of the Multinational Corporation. Columbia Journal of World Business, 4(1), 9-18.

Phelps, N., MacKinnon, D., Stone, I., Braidford, P. (2003). Embedding the multinationals? Institutions and the development of overseas manufacturing affiliates in Wales and North East England. Regional Studies, 37, 27-40.

Pierścionek, Z. (2003). Strategie konkurencji i rozwoju przedsiębiorstwa [Competition and enterprise development strategies]. Warszawa: Wydawnictwo Naukowe PWN.

Pierścionek, Z. (2011). Zarządzanie strategiczne w przedsiębiorstwie [Strategic management in the enterprise]. Warszawa: Wydawnictwo Naukowe PWN.

Porter, M.E. (1992; 2000). Strategia konkurencji. Metody analizy sektorów i konkurentów [Competition strategy. Methods for analysing sectors and competitors]. Warszawa: Polskie Wydawnictwo Ekonomiczne.

Puślecki, Ł. (2009). Realizacja aliansów technologicznych w warunkach globalizacji gospodarki światowej na przykładzie krajów Triady i Polski przedsiębiorstw [Implementation of technological alliances in the conditions of globalisation of the world economy on the example of the Triad countries and Poland]. Zeszyty Naukowe Uniwersytetu Ekonomicznego w Poznaniu, $125,47-70$.

Rogacki, H. (2006). Large industrial enterprises in Poland: changes in the regional pattern. Quaestiones Geographicae, 25, 53-59.

Romanowska, M. (2009). Planowanie strategiczne w przedsiębiorstwie [Strategic planning in the enterprise]. Warszawa: Polskie Wydawnictwo Ekonomiczne.

Rosińska- Bukowska, M. (2012). Rozwój globalnych sieci biznesowych jako strategia konkurencyjna korporacji transnarodowych. Przykład sektora motoryzacyjnego [The development of global business networks as a competitive strategy for transnational corporations. An example of the automotive sector]. Łódź: Wydawnictwo Uniwersytetu Łódzkiego.

Rymarczyk, J. (2004). Internacjonalizacja i globalizacja przedsiębiorstw [Internationalisation and globalisation of enterprises]. Warszawa: Polskie Wydawnictwo Ekonomiczne.

Rymarczyk, J. (2012a). Strategie konkurencji przedsiębiorstwa międzynarodowego [Competition strategies of an international enterprises]. Prace i Materiały Instytutu Handlu Zagranicznego Uniwersytetu Gdańskiego [Papers and Materials of the Institute of Foreign Trade of the University of Gdańsk], 31, 573-584.

Rymarczyk, J. (2012b). Biznes międzynarodowy [International business]. Warszawa: Polskie Wydawnictwo Ekonomiczne.

Sala, S. (2003). Wybrane cechy działalności korporacji transnarodowych i ich implikacje dla Polski [Selected features of transnational corporation's activities and their implications for Poland]. Prace Komisji Geografii Przemysłu Polskiego Towarzystwa Geograficznego [Studies of the Industrial Geography Commission of the Polish Geographical Society], 6, 101-109.

Sala, S. (2005). Rozwój korporacji transnarodowych w gospodarce światowej [The development of transnational corporations in the global economy]. Przedsiębiorczość-Edukacja [Entrepreneurship-Education], 1, 33-45.

Sala, S. (2008). Wpływ procesów globalizacji na region [Influence of globalization processes on a region]. Prace Komisji Geografii Przemysłu Polskiego Towarzystwa Geograficznego [Studies of the Industrial Geography Commission of the Polish Geographical Society], 10, 55-66.

Schamp, E.W. (2000). Vernetzte Produktion. Industriegeographie aus institutioneller Perspektive [Networked production. The geography of industry from an institutional perspective]. Darmstadt: Wissenchaftliche Buchgesellschaft.

Sowa, K. (2006). Strategie konkurencji korporacji ponadnarodowych [Competition strategies of transnational corporations]. Warszawa: Difin.

Stabryła, A. (2006). Strategie rozwoju firmy w kontekście internacjonalizacji [Strategies for company development in the context of internationalisation]. In: J. Rokita, W. Grudzewski (ed.). Strategie korporacji działajacych $w$ skali ponadnarodowej [Strategies of corporations operating on a supranational scale]. Katowice: Górnośląska Wyższa Szkoła Handlowa im. Wojciecha Korfantego, 11-22. 
Stępień B. (2009). Instytucjonalne uwarunkowania działalności przedsiębiorstw międzynarodowych. [Institutional determinants of the activities of international enterprises]. Poznań: Wydawnictwo Uniwersytetu Ekonomicznego w Poznaniu.

Stonehouse, G., Hamill, J., Campbell, D., Purdie, T. (2001). Globalizacja. Strategia i zarządzanie [Globalisation. Strategy and Management]. Warszawa: Felberg SJA.

Storper, M., Walker, R. (1989). The Capitalist Imperative. Territory, Technology, and Industrial Growth. New York, Oxford: Basil Blackwell.

Stryjakiewicz, T. (1999). Adaptacja przestrzenna przemysłu $w$ Polsce $w$ warunkach transformacji [Spatial adaptation of industry in Poland in the conditions of transformation]. Poznań: Wydawnictwo Naukowe Uniwersytetu Adama Mickiewicza.

Stryjakiewicz, T. (ed.) (2004). Wpływ inwestorów zagranicznych na rozwój regionalny i lokalny na przykładzie GlaxoSmithKline Pharmaceuticals S.A. w Poznaniu [The influence of foreign investors on regional and local development on the example of GlaxoSmithKline Pharmaceuticals S.A. in Poznań]. Poznań: Bogucki Wydawnictwo Naukowe.

Stryjakiewicz, T., Wajda, J. (2003). Organizacja przestrzenna grup kapitałowych jako problem badawczy geografii ekonomicznej [Spatial organisation of capital groups as a research problem of economic geography]. Prace Komisji Geografii Przemysłu Polskiego Towarzystwa Geograficznego [Studies of the Industrial Geography Commission of the Polish Geographical Society], 6, 27-49.

Śleszyński, P. (2007). Gospodarcze funkcje kontrolne w przestrzeni Polski [Economic control functions in Poland ss space]. Prace Geograficzne [Geographical Papers], 213.

Śleszyński, P. (2014). Headquarters of Large Enterprises in the Spatial Structure of Major Polish Cities. Prace Komisji Geografii Przemysłu Polskiego Towarzystwa Geograficznego [Studies of the Industrial Geography Commission of the Polish Geographical Society], 25, 178- 194.

Śleszyński, P. (2015). Economic control functions in Poland in 2013. Geographia Polonica, 88(4), 701-708.

Taylor, M., Asheim, B. (2001). The concept of the firm in economic geography. Economic Geography, 77, 315-28.

Tkocz, M., Żydzik, J. (2010). Rola światowego koncernu w przemianach przestrzeni przemysłowej Polski w okresie transformacji na przykładzie The Coca-Cola Company [Role of a world-wide company in changes of industrial space of Poland in the transformation period, with special reference to the Coca-Cola Company]. Prace Komisji Geografii Przemysłu Polskiego Towarzystwa Geograficznego [Studies of the Industrial Geography Commission of the Polish Geographical Society], 16, 153-168.

Tobolska, A. (2004a). Procesy koncentracji gospodarczej dużych przedsiębiorstw przemysłowych Poznania [Processes of economic concentration of large industrial enterprises in Poznań]. Prace Komisji Geografii Przemysłu Polskiego Towarzystwa Geograficznego [Studies of the Industrial Geography Commission of the Polish Geographical Society], 7, 33-44.

Tobolska, A. (2004b). Zmiany własnościowe i organizacyjno- ekonomiczne w wybranych dużych przedsiębiorstwach przemysłowych Poznania w okresie transformacji [Ownership, organisational and economic changes in selected large industrial enterprises of Poznań in the period of transformation]. Poznań: Bogucki Wydawnictwo Naukowe.

Tobolska, A. (2006). Strategie globalne a nowe formy organizacji przedsiębiorstw transnarodowych [Global strategies and new forms of organisation of transnational enterprises]. Przedsiębiorczość-Edukacja [Entrepreneurship-Education], 2, 125-143.

Tobolska, A. (2007). Bezpośrednie inwestycje zagraniczne a internacjonalizacja przemysłu polskiego [Foreign direct investments and the internationalisation of the Polish industry]. Prace Komisji Geografii Przemysłu Polskiego Towarzystwa Geograficznego [Studies of the Industrial Geography Commission of the Polish Geographical Society], 8, 242-256.

Tobolska, A. (2010a). Commuting as a spatial feature of international concern's location in a major city. Example of Poznań. Bulletin of Geography. Socio-economic Series, 13, 5-17.

Tobolska, A. (2010b). Miejsce inwestora zagranicznego $w$ przestrzeni lokalnej i regionalnej na przykładzie Swedwood w Chlastawie [Position of a foreign investor in local and regional space on the example of Swedwood in Chlastawa]. Poznań: Bogucki Wydawnictwo Naukowe. 
Tobolska, A. (2013). International corporations as the Focus of research in socio-economic geography. In: V.N. Kholina (ed.). Geography of the World Economy: Regionalism in the Context of Globalization. Moscow: The Peoples' Friendship University of Russia RUDN, 301-312.

Tobolska, A. (2014). Bezpośrednie inwestycje zagraniczne w przemyśle Polski: struktura działowa i przestrzenna [Foreign direct investment in the Polish industry: a division and spatial structure]. Ekonomista [Economist], 5, 733-759.

Tobolska, A. (2017). Strategie przedsiębiorstw międzynarodowych oraz ich oddziaływania $w$ przestrzeni lokalnej i regionalnej (na przykładzie wybranych koncernów przemysłowych $w$ zachodniej Polsce) [Strategies of international enterprises and their impact in local and regional space (on the example of selected industrial companies in western Poland)]. Poznań: Wydawnictwo Naukowe PWN.

Urbanowska-Sojkin, E. (1996). Strategie rynkowe podmiotów gospodarczych. In: K. Krzakiewicz (ed.). Strategie przedsiębiorstwa w procesie przechodzenia do gospodarki rynkowej. Poznań: Wydawnictwo Akademii Ekonomicznej w Poznaniu.

Urbanowska-Sojkin, E., Banaszyk, P., Witczak, H. (2004). Zarzq̨dzanie strategiczne przedsiębiorstwem [Strategic management of the enterprise]. Warszawa: Polskie Wydawnictwo Ekonomiczne.

Wajda, E., Zalewska, K. (2003). Struktura przestrzenno-organizacyjna korporacji General Motors [Spatial and organisational structure of the General Motors Corporation]. Prace Komisji Geografii Przemysłu Polskiego Towarzystwa Geograficznego [Studies of the Industrial Geography Commission of the Polish Geographical Society], 6, 119-129.

Wajda, E, Zorićić-Wołek, M. (2003). Proces kształtowania się korporacji IBM [The process of shaping the IBM Corporation]. Prace Komisji Geografii Przemysłu Polskiego Towarzystwa Geograficznego [Studies of the Industrial Geography Commission of the Polish Geographical Society], 6, 109-119.

Wąsikiewicz-Rusnak, U. (2005). Przedsiębiorstwo w procesie globalizacji [The company in the globalisation process]. Kraków: Wydawnictwo Akademii Ekonomicznej w Krakowie.

Wdowicka, M. (2005). Bezpośrednie inwestycje zagraniczne i inwestycje samorządowe w aglomeracji poznańskiej $w$ okresie transformacji ustrojowej [Foreign direct investments and local government investments in the Poznan agglomeration during the period of political transformation]. Poznań: Bogucki Wydawnictwo Naukowe.

White, R.E., Poynter, T.A. (1989). Achieving Worldwide Advantage with the Horizontal Organization. In: Business Quarterly, 55-60.

Wiederman, K. (2007). Regionalne efekty mnożnikowe rozwoju przemysłu motoryzacyjnego w aktywizacji gospodarczej województwa śląskiego [Regional multiplier effects of the development of the automotive industry in the economic activation of the Śląskie Voivodeship]. Prace Komisji Geografii Przemysłu Polskiego Towarzystwa Geograficznego [Studies of the Industrial Geography Commission of the Polish Geographical Society], 3, 24-35.

Wieloński, A. (2005). Geografia przemysłu [Geography of Industry]. Warszawa: Wydawnictwo Uniwersytetu Warszawskiego.

Winter, J. (2010). Upgrading of TNC subsidiaries: The case of the Polish automotive industry. International Journal of Automotive Technology and Management, 10(2-3), 145-60.

Wojciechowski, L. (2015). Uwarunkowania i skutki przepływu BIZ z krajów UE 15 do UE 12 na przykładzie Polski $i$ Wegier [The determinants and effects of FDI flows from the EU-15 to UE-12: The case of Poland and Hungary]. [Prace Komisji Geografii Przemysłu Polskiego Towarzystwa Geograficznego [Studies of the Industrial Geography Commission of the Polish Geographical Society], 29(1), 73-89.

Yeung, H. (2006). Firms. In: I. Douglas, R. Huggett, C. Perkins (ed.). Companion encyclopaedia of geography: From local to global. London: Routledge, 341-52.

Yip, G.S. (2004). Strategia globalna. [Global strategy] Warszawa: PWE.

Zakrzewska-Bielawska, A. (2009). Umiędzynarodowienie i globalizacja a strategie rozwoju przedsiębiorstw [Internationalisation and globalisation versus business development strategies]. In: A. Potocki (ed.). Instrumenty i obszary przeobrażeń i zmian organizacyjnych w warunkach globalizacji [Instruments and areas of transformations and organisational changes in the conditions of globalisation]. Warszawa: Difin, 339-348. 
Ząbkowicz, A. (2009). Funkcjonowanie korporacji i analizy ekonomiczne [The functioning of corporations and economic analysis]. Ekonomista [Economist], 4, 517.

Zioło, Z. (2003). Kształtowanie się przedsiębiorstw przemysłowych w procesie globalizacji [The formation of industrial enterprises in the process of globalisation]. Prace Komisji Geografii Przemystu Polskiego Towarzystwa Geograficznego [Studies of the Industrial Geography Commission of the Polish Geographical Society], 6, 9-21.

Zioło, Z. (2006). Zróżnicowanie światowej przestrzeni przemysłowej w świetle koncentracji siedzib zarządów wiodących korporacji [Diversification of the global industrial space in the light of the concentration of head offices of leading corporations]. Prace Komisji Geografii Przemystu Polskiego Towarzystwa Geograficznego [Studies of the Industrial Geography Commission of the Polish Geographical Society], 8.

Zioło, Z. (2009). Procesy kształtowania się światowych korporacji i ich wpływ na otoczenie [Global corporations' shaping processes and influence on their environment]. Prace Komisji Geografii Przemysłu Polskiego Towarzystwa Geograficznego [Studies of the Industrial Geography Commission of the Polish Geographical Society], 12, 11-32.

Zioło, Z., Piróg, S. (2002). Lokalizacja zarządów i potencjał ekonomiczny wiodących firm zachodnioeuropejskich [Location of management boards and the economic potential of leading West European companies]. Prace Komisji Geografii Przemysłu Polskiego Towarzystwa Geograficznego [Studies of the Industrial Geography Commission of the Polish Geographical Society], 4, 25-37.

Zorska, A. (1998). Ku globalizacji? Przemiany $w$ korporacjach transnarodowych $i$ w gospodarce światowej [Towards globalisation? Transformation in transnational corporations and in the global economy]. Warszawa: Wydawnictwo Naukowe PWN.

Zorska, A. (2002). Strategie KMN na rynku wyrobów przemysłowych w Polsce. In: A. Zorska (ed.). Korporacje międzynarodowe $w$ Polsce. Wyzwania $w$ dobie globalizacji regionalizacji. Warszawa: Difin, 79-109.

Zorska, A. (2007). Korporacje transnarodowe. Przemiany, oddziaływania, wyzwania [Transnational corporations. Transformations, impacts, challenges]. Warszawa: Polskie Wydawnictwo Ekonomiczne.

Zorska, A. (2013). Knowledge development and transfer in foreign subsidiaries and their parent transnational corporations. International Journal of Management and Economics, 4.

Zorska, A. (2014). Uczestnictwo filii zagranicznych w rozwoju zasobu wiedzy korporacji transnarodowych [Participation of foreign branches in the development of the knowledge base of transnational corporations]. Kwartalnik Kolegium Ekonomiczno-Społecznego. Studia i Prace [Quaternary of the Socio-Economic Commission. Studies and Papers], 2(18), 169-199.

Anna Tobolska, associate professor, a research and didactic worker at the Institute of Socio-Economic Geography and Spatial Management at the Faculty of Geographical and Geological Sciences at the Adam Mickiewicz University in Poznan. Her research interests are reflected in several dozen publications in the mainstream referring to geography of industry, the inflow of foreign direct investment, the impact of industrial enterprises in various spheres of environment at the local and regional levels, as well as studies on, among others, cross-border relations - especially on the Polish-German borderland, and changes in the socio-economic structures of small gminas of Wielkopolska. Postgraduate studies in organisation and management (Economic University in Poznań, 2005) have allowed for broadening research interests with issues related to the internationalisation processes of enterprises and organisational changes, mainly in the spatial aspect.

\section{Address:}

Adam Mickiewicz University in Poznań

Faculty of Geographical and Geological Sciences

Institute of Socio-Economic Geography and Spatial Management

ul. B. Krygowskiego 10, 61-680 Poznań, Poland

e-mail: juli@amu.edu.pl 